\title{
Engagement of Employees as Important Motivator in Telecommunication Industry in Latvia
}

\author{
${ }^{1}$ Laura Kersule, ${ }^{2}$ Biruta Sloka, ${ }^{3}$ Iluta Skruzkalne \\ ${ }^{1}$ LMT, University of Latvia \\ ${ }^{2}$ University of Latvia \\ ${ }^{3}$ Dr.oec. Motify \\ ${ }^{1}$ laura.kersule@lmt.lv, ${ }^{2}$ biruta.sloka@lu.lv, ${ }^{3}$ iluta.skruzkalne@gmail.com
}

\begin{abstract}
Aim of the paper was to inspect the mutual relations in telecommunication companies personnel motivation tools in relation to job satisfaction, in relation to engagement and in relation to motivated work behaviour in Latvia and to evaluate the possibilities of telecommunication companies to realise the employee engagement and create the tool could be used to measure this aspect. For a more thorough data analysis (used evaluation scale 1-7) statistical indicators measuring of central tendency or location degree means and structural means, as well as dispersion, methods of multivariate analysis for dimension reduction, regression, correlation. Research results reveal on use in more work engagement is one of the most motivating factors in telecommunication industry.
\end{abstract}

Keywords: Employee motivation, engagement, information technologies and communication, salary, factor analysis. 


\section{Introduction}

Many countries around the globe are looking for innovatiove tools for keeping employees in information technologies and communication as the technologies has fast development and employees have to be retrained and their skills updated from one sine and motivation to stay in the industry from other side ans qualifies specialists are under big attention of "head - hunters" and involving high level speciālists in other brances. Need for specialists in information technologies and communication in Latvia is increasing but in many telecommunication companies employees are loyal to the companies and are ready to go on with their work there. The statistical data of salaries in different branches confirm that information technologies and communications branch are motivating their employees with bigger salaries and developed motivation systems to keep and motivate emplyees. Motivation of people becomes increasingly important. One of motivation aspects is engagement which has big importance for loyality of the employees to their company and respective branch.

\section{Theoretical Findings}

Researchers world - wide are analysing competitive employees aspects in several dimensions and offer findings related to involvement in employment (Raudeliūnienè, et al, 2021, Raudeliūnienè \& Szarucki, 2019; Davidaviciene, et al, 2019; Tang. \& Cheung, 2010; Tang, et al, 2017), training on required skills as in information Technologies and communication there are big and rapid changes annually.

Employee motivation and related to it factors and various- aspects are investigated by many researchers (Kumar \& Pansari, 2014; Xanthopoulou, et al, 2009: Zigarmi, et al, 2009: Cerasoli \& Nicklin \& Ford, 2014; Bakker \& Demerouti, 2008; Sloka, Kersule\& Skruzkalne, 2020). Several changes are taking place in the economic development especially in several industries, like telecommunications where the technology changes very often and it is important to update the requirements for employees to fulffil their duties and devote their creative involvement taking into account psychological requirements in regulary changing work environment leaving back physical requirements. To observe the influence of changes in longer or shorter time period on different levels at the company, human capital and management of the human capital has become one of the recent century as most important aspect in the actively producing companies. For the employee engagement has to be found the ways of reaching higher results and especially for suggesting better possible management decisions.

Telecommunications service branch strategically has shown that human resources are very sensitive in comparision with than other production factors, as it is recognised that human resources is the main factor in getting and keeping skilled personnel in the field - researchers are investigating several other aspects as well 
(Rezghdeh \& Shokouhyar, 2020; Rana \& Chhabra, 2011; Xu, Zhao, Xi \& Zhao, 2018; Sloka, Kersule \& Skruzkalne, 2020; Kersule, Sloka \& Skruzkalne, 2019; Kersule, 2018). In the respective branch companies have created and developed telecommunication products and services as it is recognized also by academic researchers that the engagement of very skilled employees become a very attractive and wanted sourcce regarding demand for highly qualified specialists (Sloka, Kersule \& Skruzkalne, 2020).

Employee engagement has been researched by researchers for different research fields (psychology, management, muman resources and is recognized as an interdisciplinary issue. Theoretically it was analysed deeply and definitions developed in the field of psychology which is used in practical work of companies especially in the telecommunications industry where the employee engagement is recognized in relation to the development as well as to the improvement of various final performance indicators which are very important for the respective company.

The currents research findings indicate that in Latvia documents and research the definitions of employee engagement, employee engaging and employee job involvement are used as synonims, but by author's thougths they should be conceptually separated. The authors (Sloka, Kersule \& Skruzkalne, 2020) have recommended for use in the research.

Employee engagement is analysed in relation with the expression of their behaviour, integrating together attitudes and behavioural aspects (Rezghdeh \& Shokouhyar, 2020; Recalde \& Gutiérrez-García, 2017; Vankatesh, Bala \& Sykes, 2010; Kersule, Sloka \& Skruzkalne, 2019; Kersule, 2018).

In research findings two engagement approaches are suggested that have inspired other researchers by Kahn (Kahn, 1990) and Schaufeli (Schaufeli, 2013; Schaufeli, et al, 2002) as well as in recent research results presentations (Sloka, Kersule \& Skruzkalne, 2020; Kersule, Sloka \& Skruzkalne, 2019; Kersule, 2018).

In scientific findings there are different ways to measure employee engagement with the most often used scale (UWES or Utrecht scale) which is used in $85 \%$ reaearches (Bailey, et al, 2017, p.43), different scales are suggested as well (Buligina \& Sloka, 2013).

The engagement scale should reflect the main aspects covered by the founder of the engagement theory Kahn in 1990 (Kahn, 1990) and often are used in other author's scientific publications (Foster, 2010; Katou \& Budhwar, 2015; Kersule, Sloka \& Skruzkalne, 2019; Kersule, 2018) integrating in the concept of engagement very important aspects: behaviour, emotional and cognitive dimensions.

\section{Empirical Research Results}

Information and communication technologies employees are among the best paid employees in Latvia where there are distribution of salaries total in Latvia and employees in information and communication technologies in 2021 February is 
reflected in Fig. 1.

The evaluations of different employee engagement aaspects are evaluated by respondents and results are can be seen in Table 1.

The highest average evaluations given by the respondents (with the biggest arithmetic mean of the evaluations, with most often given evaluation by respondents - highest possible value from the applied evaluation scale and $50 \%$ of respondents included in the sample evaluated by 7 or less and $50 \%$ of respondents evaluated with 7) which were for the statement in the survey "I understand how my team/department facilitates the common success of the company", distribution of responses (with one of the smallest differences in evaluations characterised by indicators of dispersion) is reflected in Fig. 2.

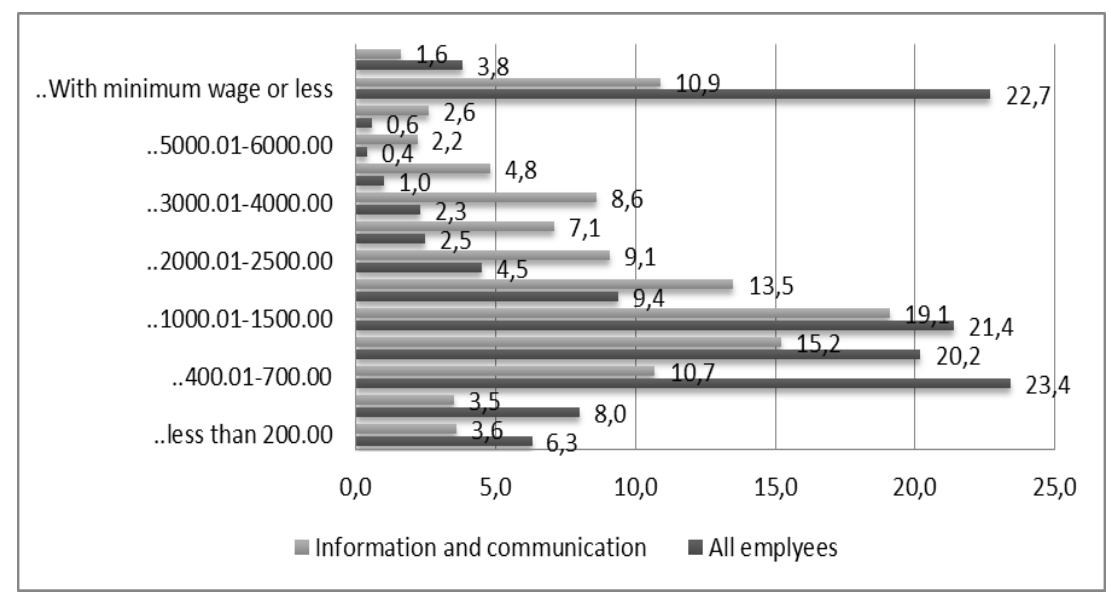

Source: Authors' construction based on CSB data

Fig. 1: Distribution of share of employees by salaries all employees and information and communication technologies employees (in percent) in February 2021

Table 1: Main statistical characteristics reflecting engagement

\begin{tabular}{|c|c|c|c|c|c|c|c|c|c|c|}
\hline \multirow[b]{2}{*}{ Statistical indicators } & \multicolumn{2}{|c|}{$\mathbf{N}$} & \multirow{2}{*}{$\begin{array}{l}\text { Mea } \\
\text { n }\end{array}$} & \multirow{2}{*}{$\begin{array}{l}\text { Std. } \\
\text { Error } \\
\text { of } \\
\text { Mean }\end{array}$} & \multirow{2}{*}{$\begin{array}{l}\text { Me } \\
\text { dia } \\
\text { n }\end{array}$} & \multirow{2}{*}{$\begin{array}{l}\text { Mo } \\
\text { de }\end{array}$} & \multirow{2}{*}{$\begin{array}{l}\text { Std. } \\
\text { Deviat } \\
\text { ion }\end{array}$} & \multirow[b]{2}{*}{$\begin{array}{l}\text { Ran } \\
\text { ge }\end{array}$} & \multirow[b]{2}{*}{ Mini } & \multirow[b]{2}{*}{ Max } \\
\hline & $\begin{array}{l}\text { Vali } \\
\text { d }\end{array}$ & $\begin{array}{l}\text { Miss } \\
\text { ing }\end{array}$ & & & & & & & & \\
\hline $\begin{array}{l}\text { I am doing a } \\
\text { significant and } \\
\text { meaningful job }\end{array}$ & 608 & 0 & 6.03 & 0.039 & 6 & 6 & 0.968 & 6 & 1 & 7 \\
\hline $\begin{array}{l}\text { I feel that my job } \\
\text { gives me professional } \\
\text { satisfaction }\end{array}$ & 608 & 0 & 5.41 & 0.046 & 6 & 6 & 1.139 & 6 & 1 & 7 \\
\hline $\begin{array}{l}\text { I am proud that I } \\
\text { work in this company }\end{array}$ & 608 & 0 & 6.33 & 0.035 & 7 & 7 & 0.875 & 4 & 3 & 7 \\
\hline
\end{tabular}




\begin{tabular}{|c|c|c|c|c|c|c|c|c|c|c|}
\hline $\begin{array}{l}\text { I understand how my } \\
\text { team/department } \\
\text { facilitates the } \\
\text { common success of } \\
\text { the company } \\
\end{array}$ & 608 & 0 & 6.34 & 0.036 & 7 & 7 & 0.881 & 6 & 1 & 7 \\
\hline $\begin{array}{c}\text { I am personally } \\
\text { motivated to make } \\
\text { this company better }\end{array}$ & 608 & 0 & 6.16 & 0.037 & 6 & 7 & 0.92 & 5 & 2 & 7 \\
\hline $\begin{array}{l}\text { I care on results of } \\
\text { our company and I } \\
\text { am ready to devote } \\
\text { additional efforts for } \\
\text { that }\end{array}$ & 608 & 0 & 6.19 & 0.036 & 6 & 7 & 0.895 & 6 & 1 & 7 \\
\hline $\begin{array}{c}\text { I support my } \\
\text { company in my social } \\
\text { activities }\end{array}$ & 608 & 0 & 5.65 & 0.057 & 6 & 7 & 1.416 & 6 & 1 & 7 \\
\hline $\begin{array}{l}\text { In this work I try to } \\
\text { do the best even if it } \\
\text { make me difficulties }\end{array}$ & 608 & 0 & 5.88 & 0.035 & 6 & 6 & 0.873 & 4 & 3 & 7 \\
\hline $\begin{array}{l}\text { I this work I do not } \\
\text { feel how time is } \\
\text { running }\end{array}$ & 608 & 0 & 5.83 & 0.045 & 6 & 7 & 1.121 & 6 & 1 & 7 \\
\hline $\begin{array}{l}\text { I like to meet my } \\
\text { colleagues as it is } \\
\text { among the most } \\
\text { important aspects in } \\
\text { my work }\end{array}$ & 608 & 0 & 4.95 & 0.056 & 5 & 5 & 1.378 & 6 & 1 & 7 \\
\hline $\begin{array}{l}\text { I know clearly what is } \\
\text { expected from me in } \\
\text { my job }\end{array}$ & 608 & 0 & 6.02 & 0.039 & 6 & 6 & 0.951 & 6 & 1 & 7 \\
\hline $\begin{array}{l}\text { My opinions and } \\
\text { ideas are important to } \\
\text { the company }\end{array}$ & 608 & 0 & 5.07 & 0.053 & 5 & $5 ; 6$ & 1.305 & 6 & 1 & 7 \\
\hline
\end{tabular}

Source: Authors calculations based on survey results with evaluation scale 1-7, sample size 608

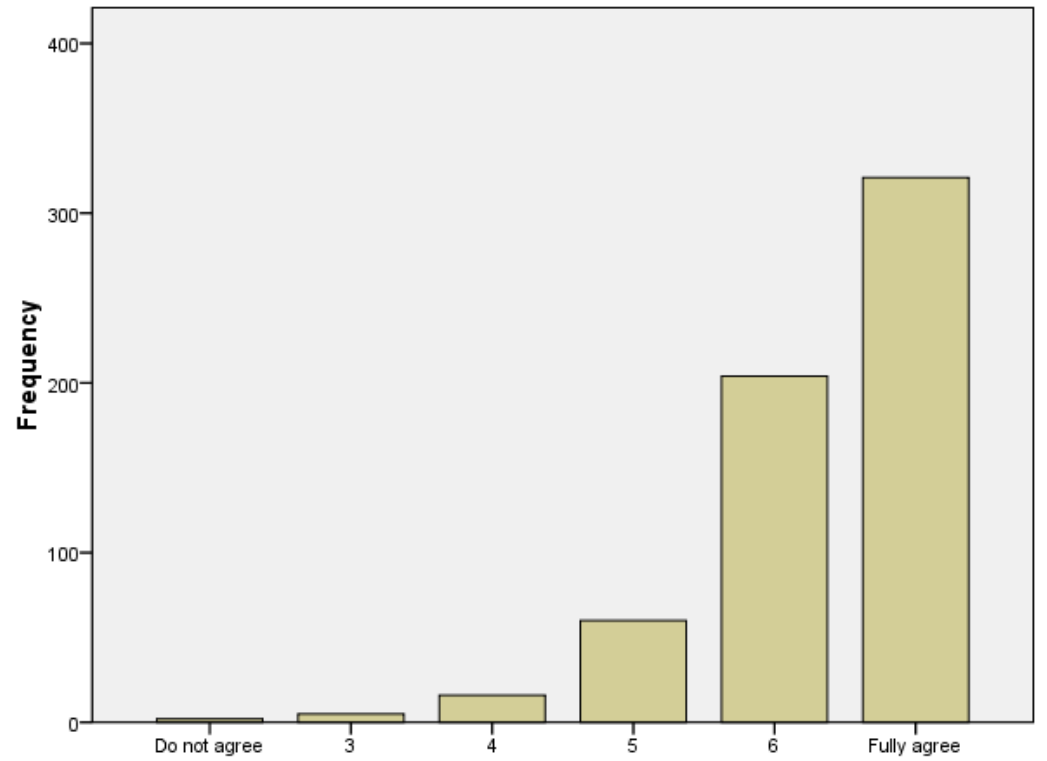


Source: Authors construction based on survey results with evaluation scale 1-7, sample size 608.

Fig. 2: I understand how my team/department facilities the common success of the company

Table 2: Testing hypothesis with $\mathrm{t}$ - test on evaluations by gender on statement "I understand how my team/department facilitates the common success of the company"

\begin{tabular}{|c|c|c|c|c|}
\hline \multicolumn{5}{|c|}{ Group Statistics } \\
\hline Gender & N & Mean & Standard Deviation & Standard Error of Mean \\
\hline Female & 289 & 6.29 & 0.892 & 0.052 \\
\hline Male & 319 & 6.38 & 0.871 & 0.049 \\
\hline
\end{tabular}

\begin{tabular}{|c|c|c|c|c|c|c|c|}
\hline & F & Sig. & t & df & $\begin{array}{c}\text { Sig. (2- } \\
\text { tailed) }\end{array}$ & $\begin{array}{c}\text { Mean } \\
\text { Difference }\end{array}$ & $\begin{array}{c}\text { Std. Error } \\
\text { Difference }\end{array}$ \\
\hline Equal variances assumed & 0.086 & 0.770 & -1.288 & 606 & 0.198 & -0.092 & 0.072 \\
\hline $\begin{array}{c}\text { Equal variances not } \\
\text { assumed }\end{array}$ & & & -1.286 & 596.961 & 0.199 & -0.092 & 0.072 \\
\hline
\end{tabular}

Source: Authors calculations based on survey results with evaluation scale 1-7, sample size 608.

Table 3. Testing statistical hypothesis with analysis of variance - ANOVA on evaluations by years worked in the company on the statement "I understand how my team/department facilitates the common success of the company"

\begin{tabular}{|c|c|c|c|c|c|}
\hline & Sum of Squares & df & Mean Square & F & Sig. \\
\hline Between Groups & 812476.560 & 5 & 162495.312 & 2.319 & .042 \\
\hline Within Groups & $4.219 \mathrm{E} 7$ & 602 & 70086.254 & & \\
\hline Total & $4.300 \mathrm{E} 7$ & 607 & & & \\
\hline
\end{tabular}

Source: Authors calculations based on survey results with evaluation scale 1-7, sample size 608 .

The study confirms that employee engagement can be influenced, and most likely it is the personnel management practice in organisations that will have the crucial significance in encouraging employee engagement. Both the conclusions of other researchers and this study point to the significant role of work resources, nature of the work and the organisation's support in creating and maintaining employee engagement. Consequently, personnel management practice has an essential role in motivating employees by strategically planning and offering work resources, e.g. autonomies and flexible work systems, increasing employee authorities, providing them with relevant information, knowledge and feedback, which directly and to a great extent influence employee engagement in work roles and tasks.

The main outcomes of factor analysis of the author's calculations are included in 
Table 3, where from the initial variables (statements rated by respondents), as a result of the diminsion reduction by most often used method of multivariate analysis - factor analysis, two complex factors were separated in 3 iterations. As a result of dimensions reduction by factor analysis it is concluded that two complex factors could be determined as:

Employee personal attitude factor;

Company managerial factor.

Table 4. Reduction of dimensions by factor analysios reflecting engagement engagement

\begin{tabular}{|l|c|c|}
\hline & \multicolumn{2}{|c|}{ Component } \\
\hline & $\mathbf{1}$ & $\mathbf{2}$ \\
\hline I am doing a significant and meaningful job & .746 & .230 \\
\hline I feel that my job gives me professional satisfaction & .747 & .287 \\
\hline I am proud that I work in this company & .366 & .662 \\
\hline $\begin{array}{l}\text { I understand how my team/department facilitates the common success of } \\
\text { the company }\end{array}$ & .423 & .607 \\
\hline I am personally motivated to make this company better & .441 & .681 \\
\hline $\begin{array}{l}\text { I care on results of our company and I am ready to devote additional } \\
\text { efforts for that }\end{array}$ & .419 & .741 \\
\hline I support my company in my social activities & -.024 & .755 \\
\hline In this work I try to do the best even if it make me difficulties & .297 & .685 \\
\hline I this work I do not feel how time is running & .504 & .346 \\
\hline $\begin{array}{l}\text { I like to meet my colleagues as it is among the most important aspects in } \\
\text { my work }\end{array}$ & .500 & .152 \\
\hline I know clearly what is expected from me in my job & .633 & .136 \\
\hline My opinions and ideas are important to the company & .696 & .278 \\
\hline
\end{tabular}

Extraction Method: Principal Component Analysis.

Rotation Method: Varimax with Kaiser Normalization

Rotation converged in 3 iterations.

Source: Authors calculations based on survey results with evaluation scale 1-7, sample size 608

During the research the author, in analysing engagement's close concepts, asked the question of whether engagement is a precondition for commitment to the organisation, or whether it is the opposite - commitment to an organisation as an emotional aspect (that creates security), causes employee engagement and activity. In his scientific publication of 1974 that is widely used in the world, Porter, in defining engagement and commitment to an organisation, pointed out that an employee committed to the organisation accepts its aims and values, shows readiness to put additional effort in for the good of the organisation and demonstrates the wish to continue to commit to the organisation. Theoretically, 
engagement is defined as an attitude factor (connecting one's future with the organisation); in the author's model it partially overlaps the supportive organisation's behaviour, OCB — organisational citizenship behaviour), which, theoretically, is a concept of both attitude and behaviour.

The outcomes of this study are more in favour of the assumption that employee engagement influences commitment to an organisation. However, this statement needs further research focused on the analysis of these links: engagement and commitment to an organisation. In this case, one of the forms of commitment, emotional, is fulfilled. Both others - relation-connected commitment formed an individual factor - intention to stay with the organisation, which did not yield powerful statistical outcomes. The engagement model offered by the author includes such variables that correspond to the principles of the engagement conceptualisation published by William A. Kahn (Kahn, 1990) which is respected and applied by other researchers which states that engagement is determined by three psychological conditions: job meaningfulness, psychological safety, and the presence (experienced availability) of the employee. The author's model and the outcomes of the analysis also confirm conclusions by other researchers that they significantly affect employee engagement. There are several variables that form the factor 'satisfaction with work' in the author's model, and they can be related to the psychological conditions 'job meaningfulness', which unites intrinsic motivators connected with job autonomy, responsibility, development etc., and 'psychological safety', which unites other intrinsic motivators such as harmony of values, significance of employee opinion, identification with an organisation.

\section{Conclusions}

Engagement as motivation toll is on great importance in many fields and with special importance for telecommunications. Employee engagement influences commitment to an organisation. Engagement is defined as an attitude factor (connecting one's future with the organisation. Intrinsic motivators, or those directly related to work have a larger impact on engagement as a dependent or outcome variable - an increase of one's perceptions on the autonomy and growth rating by one unit would change the engagement assessment.

\section{Acknowledgements}

The paper is supported by National Research Programme INTERFRAME-LV. 


\section{References}

Bailey, C., Madden, A., Alfes, K. \& Fletcher L. (2017). The Meaning, Antecedents and Outcomes of Employee Engagement: A Narrative Synthesis. International Journal of Management Review, 19, 31-53.

Bakker, A.B. \& Demerouti, E. (2008). Towards a model of work engagement. Career Development International, 13(3), 209-223.

Buligina, I. \& Sloka, B. (2013). Matching vocational training and labour market demands - The opinion of public administrations. Economic Research-Ekonomska Istrazivanja, 26, 299-310.

Central Statistics Bureau (2021). Database on Salaries and Wages.

Cerasoli, C.P., Nicklin, J.M. \& Ford, M.T. (2014). Intrinsic motivation and extrinsic incentives jointly predict performance: a 40-year meta-analysis. Psychology Bullettin, 140(4), 980-1008.

Davidaviciene, V., Raudeliuniene, J., Tvaronaviciene, M. \& Kaušinis, J. (2019). The importance of security aspects in consumer preferences in electronic environment, Journal of Security and Sustainability Issues, 8(3), 399-411.

Foster, R. (2010). Resistance, Justice and Commitment to Change. Human Resource Development Quarterly, 21(1), 3-39.

Kahn, W. (1990). Psychological conditions of personal engagement and disengagement at work, Academy of Management Journal. 33(4), 692-724.

Katou, A.A. \& Budhwar, P. (2015). Human resource management and organisational productivity: A systems approach based empirical analysis. Journal of Organizational Effectiveness: People and Performance, 2(3), 244-266.

Kersule, L., Sloka, B. \& Skruzkalne, I. (2019). Employee Motivators in Telecommunication Companies in Latvia, International Scientific Conference on The Impact of Industry 4.0 on Job Creation, 22.11.2018, Alexander Dubcek University, Trencin, Slovakia, 89-100.

Kersule, L 2018. Employee Engagemrent Analysis Evaluation - Papproaches, Results and Challenges. Journal of Economic and Management Research, 7, 58-74. 
Kumar, V. \& Pansari, A. (2014). The Construct, Measurement, and Impact of Employee Engagement: a Marketing Perspective. Customer Needs and Solutions, 1, 52-67.

Rana, N. \& Chhabra, N.L. (2011). Employee Engagement: A primer for strategic human resource management, Asian Journal of Research in Business, Economics and Management, 1(2), 16-27.

Raudeliūnienè, J., Davidavičienè, V., Meidutè-Kavaliauskienė, I. \& Radeckytė, V. (2021). Women's leadership success factors in the Baltic states. International Journal of Learning and Change, 13(2), 171-189.

Raudeliuniene, J. \& Szarucki, M. (2019). An integrated approach to assessing an organization's knowledge potential. Engineering Economics, 30(1), 69-80.

Recalde, M. \& Gutiérrez-García, E. (2017). Digital natives: the engagement experience to online protection, Young Consumers, 18(2), 159-179.

Rezghdeh, K. \& Shokouhyar, S. (2020). A six-dimensional model for supply chain sustainability risk analysis in telecommunication networks: a case study, Modern Supply Chain Research and Applications, 2(4), 1-246.

Rupeika-Apoga, R., Romānova, I., Bule L. \& Thalassinos Y.E. (2019). The Impact of Population Ageing and Social Stratification: The Case of Latvia. International Journal of Economics and Business Administration, 7(1), 49-63.

Schaufeli, W.B. (2013). What is engagement? In C. Truss, K. Alfes, R. Delbridge, A. Shantz, \& E. Soane (Eds.), Employee Engagement in Theory and Practice. London: Routledge.

Schaufeli, W.B., Salanova, M., Gonzalez-Roma, V. \& Bakker, A.B. (2002). The measurement of engagement and burnout: A two sample confirmatory factor analytic approach. Journal of Happiness Studies, 3(1), 71-92.

Sloka, B., Kersule, L. \& Skruzkalne, I. 2020. The Role of Telecommunication Personnel for Industry 4.0 Job Creation, International Scientific Conference on The Impact of Industry 4.0 on Job Creation, 21.11.2019, Alexander Dubcek University, Trencin, Slovakia, 355-363.

Tang, M., Li, M. \& Zhang, T. (2016). The impacts of organizational culture on information security culture: a case study, Information Technology and Management, 17(2), 179-186. 
Tang, M. \& Cheung, W. (2010). ERP decisions: The role of organizational culture and SCM practices. Proceedings of the International Conference on Electronic Business (ICEB), 2010, 540-547.

Vankatesh, V., Bala, H. \& Sykes, T.A. (2010). Impacts of Information and Communication Technology Implementation on Employees' Jobs in Service Organizations in India. Production and Operation Management, 19(5), 591-613.

Xanthopoulou, D., Bakker, A.B., Demerouti, E. \& Schaufeli, W.B. (2009). Work engagement and financial returns: a diary study on the role of job and personal resources. Journal of Occupational and Organizational Psychology, 82(1), 183-200.

Xu, Q., Zhao, Y., Xi, M. \& Zhao, S. (2018). Impact of benevolent leadership on follower taking charge: Roles of work engagement and role-breadth self-efficacy, Chinese Management Studies, 12(4), 741-755.

Zigarmi, D., Nimon, K., Houson, D., Witt, D. \& Diehl, J. (2009). Beyond engagement: toward a framework and operational definition for employee work passion. Human Resource Development Review, 8(3), 300-326. 